\title{
Endoscopic full-thickness resection of fistula tract with suture closure
}

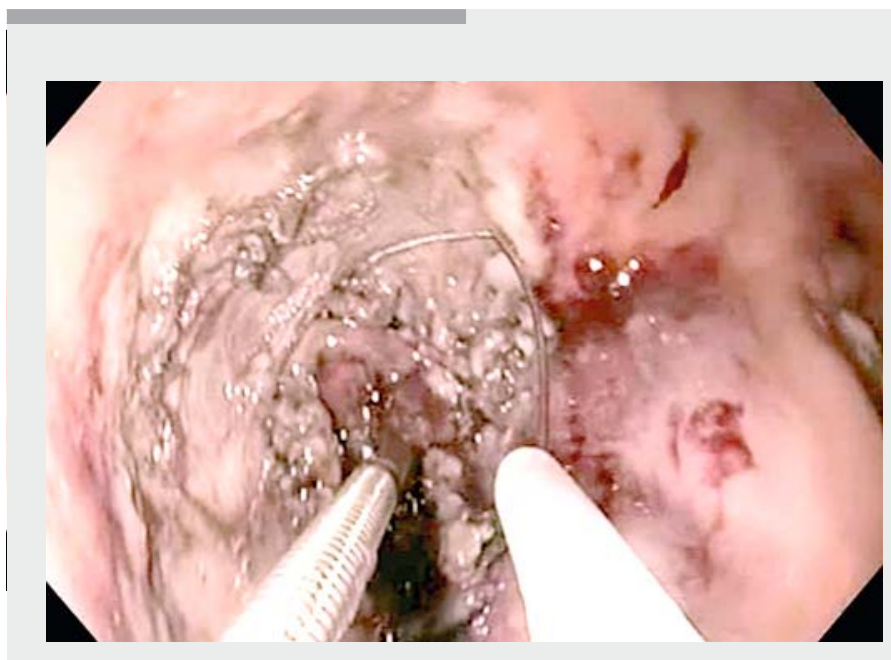

$\checkmark$ Video 1 Endoscopic submucosal dissection with full-thickness resection of fistula tract and suture closure.

A 59-year-old man, with a history of Roux-en-Y gastric bypass 9 years previously, presented with chronic epigastric pain thought to be due to recurrent marginal ulceration. On diagnostic endoscopy he was found to have a $3-\mathrm{cm}$ gastric pouch and a $18-\mathrm{mm}$ gastrojejunal anastomotic diameter. Additionally, a 1-cm cratered ulceration on the jejunal aspect of the post-bypass anastomosis and a 3-mm fistulous opening in the distal gastric pouch were noted. The presence of bubbles when the area was flooded with water suggested a fistulous communication between the gastric pouch and the remnant stomach.

The area was injected with diluted 1:10000 epinephrine mixed with methy- lene blue to lift the fistulous opening. An electrosurgical knife was used to create an incision in the mucosa, and an insulated-tip needle-knife was used to encircle the area. Standard endoscopic submucosal dissection technique was used. The tissue was brought into a snare using forceps, and the fistulous tract and the surrounding dissected mucosa was resected with snare cautery ( $\vee$ Video 1 ). The resected site was closed with a running stitch created using an endoscopic suturing device, and 3 additional interrupted reinforcement stitches were placed.

The patient's abdominal pain resolved 2 weeks after the procedure. An upper gastrointestinal series 3 months later confirmed closure of the fistula and evidence of recurrent marginal ulceration.

Gastrogastric fistula is a recognized complication of gastric bypass. However, fistula closure rates remain low with current endoscopic treatment methods. One initial study of endoscopic fistula closure in 95 patients showed recurrent fistula in 65\% [1]. Another multicenter trial using a full-thickness endoscopic suturing device alone $(n=29)$ showed $100 \%$ immediate technical success but a closure rate of $17.1 \%$ after 12 months [2]. The novel technique described here utilizes surgical principles by combining endoscopic submucosal dissection together with fistula tract resection, which may allow for better apposition of healthier tissue and improve successful long-term closure.

Endoscopy_UCTN_Code_TTT_1AO_2AI

Competing interests

C.C. Thompson: Boston Scientific - Consultant (Consulting fees); USGI Medical - Consultant (Consulting Fees)/Advisory Board Member (Consulting fees)/Research Support (Research Grant); Olympus - Consultant (Consulting Fees)/Research Support (Equipment Loans); Apollo Endosurgery - Consultant/Research Support (Consulting fees/Institutional Research Grants); Aspire Bariatrics - Research Support (Institutional Research Grant). H. Aihara: Olympus - Consultant (Consulting Fees).

A. L. Chiang and A.C. Storm: Nothing to disclose. 
The authors

Austin L. Chiang, Andrew C. Storm, Hiroyuki Aihara, Christopher C. Thompson

Division of Gastroenterology, Hepatology and Endoscopy Brigham and Women's Hospital

Boston, Massachusetts, United States

Corresponding author

\section{Christopher C. Thompson, MD}

Division of Gastroenterology, Hepatology and Endoscopy Brigham and Women's Hospital, 75 Francis St., ASBII Boston Massachusetts 02115, United States Fax: 01-617-525-8266

cthompson@hms.harvard.edu

\section{References}

[1] Fernandez-Esparrach G, Lautz DB et al. Endoscopic repair of gastrogastric fistula after Roux-en-Y gastric bypass: a less-invasive approach. Surg Obes Rel Dis 2010; 6: $282-289$

[2] Mukewar S, Kumar N, Catalano M et al. Safety and efficacy of fistula closure by endoscopic suturing: a multi-center study. Endoscopy 2016; 48: $1023-1028$

\section{Bibliography}

DOI https://doi.org/10.1055/s-0043-118213

Published online: 25.10.2017

Endoscopy 2018; 50: E15-E16

(c) Georg Thieme Verlag KG

Stuttgart · New York

ISSN 0013-726X

\section{ENDOSCOPY E-VIDEOS}

https://eref.thieme.de/e-videos

回的 Endoscopy E-Videos is a free access online section, reporting 国: on interesting cases and new techniques in gastroenterological endoscopy. All papers include a high quality video and all contributions are freely accessible online.

This section has its own submission website at

https://mc.manuscriptcentral.com/e-videos 